\title{
THE LAST PASSENGER PIGEON
}

\author{
Hope springs eternal.
}

\section{BY JOY KENNEDY-O'NEILL}

\section{"S} tevie!”

My neighbour, Mrs Wilkins, knocked at my backdoor.

"It's Stephan," I muttered. I was 30 years old, but sometimes she made me feel like I was 12 . The house-cam projected her image in front of me - white hair, rumpled robe and twigs of hedgerow stuck in her slippers. Her eyes wide and frantic. She held something feathery in her trembling hands.

"Look at what Pumpkin brought me! Dropped it right at my feet."

I opened the door and saw a dead bird.

"What is it?" she asked. "A toy?"

"Holy ...!" I took it in my hands. Bits of gears stuck to the dove-grey feathers. The body was still warm, but its bio-servo was cooling quickly. The eyes blinked once, then closed. I saw the limited-edition number around its banded leg.

"It's a Hayashi original," I said.

"A what?"

I looked at the iridescent neck feathers, the spotted wings. Its chest was half opened and macerated, but I could see that its breast feathers were the colour of a rosy dawn. The last of the Passenger Pigeon Extinction series.

Ruined.

"Mrs Wilkins, this is serious -"

"I know, I know! I'm not supposed to let Pumpkin out. It's illegal."

Twining around her legs was a fat, selfsatisfied, orange puffball of a cat. His ears twitched at the sounds of the backyard's usual sparrows and cardinals.

"We have to call someone," I said.

"Oh no, no! We can bury it. No one needs to know. That's why I came around out back."

I picked up some feathers, including a tiny spring and pinhead screws. A real Hayashi had been singing right here. There had once been millions of the real ones. They rolled in great clouds of wing and birdcall.

Mrs Wilkins took my elbow and whispered. "The men in the street. You think they're looking for it?"

My stomach sank.

I helped her back through the hedgerow. It's an old neighbourhood, still on a solar grid and city water. In another 20 years, this block will be gentrified. When my wife and I first moved in, we loved the potential. Of

course, that was before the divorce. Before she met the lanky sous chef in her night class.

Mrs Wilkins' house had that old-lady smell of stale perfume and dust. She's the last of her kind here. I peeped out of her front window and sure enough, two men were on the sidewalk looking up at the green treetops. One had old-fashioned binoculars; the other wore rubber waders.

"I'll make you some coffee," she said.

I shut her back door firmly, eyeing the cat. I put the bird's remains down on a lace doily.

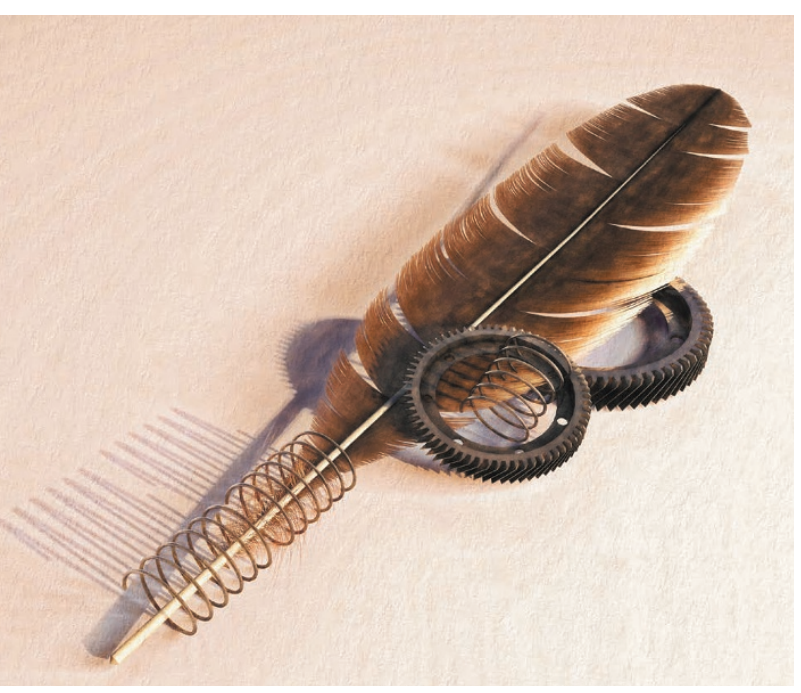

I can't believe it! I thought to myself, again. A real Hayashi. Right here. It's like she found a Rembrandt in her closet. I looked at the tiny vivo-2 silicon nitride gears, the brass antebrachial pinions.

"Nice to have company," Mrs Wilkins murmured. "I should call my daughter. You'd like her. She's single now, too."

I gritted my teeth. Being broken-hearted for six months, a year ... maybe it's like being a birder. I was always looking for the flit of her scarf, or the colour of her hair in a crowd. And part of me was angry that she hadn't even lied to me.

A knock, and Mrs Wilkins' house-cam showed the men right at her front door. My heart thudded; my palms got sweaty.

"I'll take care of it," I said.

The men wore Audubon Society badges. The man with the antique binoculars was

$\rightarrow$ NATURE.COM

Follow Futures: y @NatureFutures

f go.nature.com/mtoodm older. The younger one's eyes were blue and bright, and I figured he wore zooming contacts that backed up content in an external memory.

At first they seemed threatening, but then the older one smiled. "Hi there!" he said. "We're birders, looking for a Hayashi pigeon."

"A Hayashi? There's still some left?" I feigned innocence.

"Maybe. Or at least one. We've heard some reports of sightings. It would look a lot like a dove, but with a colourful chest. Red eyes and feet."

I tried not to think of the wreck on Mrs Wilkins' table. I knew that Yuto Hayashi made only 150 of the birds, decades ago. It was a homage, a tribute to loss.

"It might make a cooing sound," the older man said. "Totally realistic."

"Uh, ok. I'll keep my eyes open.” I was trying to close the door, hoping Pumpkin didn't make an escape.

"Everybody tells us it's too bad he didn't give the birds a beacon signal, right?" the younger one said.

"Uh, yeah?" I asked.

"But he knew."

"Knew what?"

"Had to be in the wild," the older man said. "That was the art of it. It's the looking that's important."

I heard Mrs Wilkins run the disposal in her kitchen, and detected the clinking grind of metal on metal. My stomach churned.

"Well, I’ll certainly keep my head up," I said.

We exchanged numbers and I closed the door. Then they were off, walking down the street, looking at yards, searching the treetops.

At first I congratulated myself for getting Mrs Wilkins out of this mess. I was surprised at how easily I had lied.

But when I think about it, and when I look at a sky that's the colour of lost things, it was more than that. I imagine the men walking down miles of dark streets, across fields, stomping through puddles in public parks, always looking for that flash of colour, that flicker of a life just out of reach.

I had to leave them that. I had to leave them hope.

Joy Kennedy-O'Neill teaches English at a small college on the Texas Gulf Coast. Her speculative fiction can be found in Strange Horizons, Flash Fiction Online, Daily Science Fiction and collections by Prime Books and Paper Golem Press. 